\title{
Beyond Darwin: On the role of niche construction and self-organization in evolution
}

\author{
Más allá de Darwin: acerca del rol de la construcción de nicho y la autoorganización \\ en evolución
}

PABLO A. MARQUET

\begin{abstract}
Center for Advanced Studies in Ecology and Biodiversity (CASEB)
Departamento de Ecología, Facultad de Ciencias Biológicas, Pontificia Universidad Católica de Chile, Casilla 114-D, Santiago, Chile

Institute of Ecology and Biodiversity (IEB), Facultad de Ciencias Universidad de Chile, Casilla 653, Santiago, Chile The Santa Fe Institute, 1399 Hyde Park Road, Santa Fe, New Mexico 87501, USA

e-mail:pmarquet@bio.puc.cl
\end{abstract}

\begin{abstract}
In this essay I point out to two processes that can potentially complement the classical view of evolution by natural selection as outlined by Darwin, which captures only part of the processes driving adaptive evolution. This classical view should be complemented with sources of order generated within the biological system itself in response to its own structure and dynamics (i.e. self-organization) and by considering the existence of a fundamental circularity in the interaction between the organism and its environment, such that the action of the organisms modify their selective environment thereby affecting their own evolution. The formalization and inclusion of these two processes (and their interaction) represent major challenges and opportunities for the expansion of evolutionary theory in the Darwinian tradition.
\end{abstract}

Key words: Darwin, natural selection, self-organization.

\section{RESUMEN}

En este ensayo argumento acerca de dos procesos que potencialmente complementan la visión darwinista clásica de la evolución por selección natural. Esta visión clásica debiera ser complementada con la consideración de fuentes de orden generadas dentro del sistema biológico mismo en respuesta a su propia estructura y dinámica (i.e. autoorganización) y por la consideración de la existencia de una circularidad fundamental en la interacción entre el organismo y su ambiente, tal que la acción del organismo modifica el ambiente selectivo al cual está expuesto y por lo tanto afecta su propia evolución, lo que se denomina construcción de nicho. La formalización e inclusión de estos dos procesos (autoorganización y construcción de nicho) representa un gran desafío y oportunidad para la expansión de la teoría evolutiva en la tradición Darwiniana.

Palabras clave: autoorganización, Darwin, selección natural.

"Owing to this struggle for life, any variation,
however slight and from whatever cause
proceeding, if it be in any degree profitable to an
individual of any species, in its infinitely
complex relations to other organic beings and to
external nature, will tend to the preservation of
that individual, and will generally be inherited
by its offspring ... I have called this principle, by
which each slight variation, if useful, is preserved, by the term of Natural Selection, in order to mark its relation to man's power of selection." (Charles Darwin 1959, pp. 60-61).

Darwin's theory of evolution through natural selection (NS, hereafter) entails a two step iterative variation-selection process with memory: generation of random genetic variation by processes of mutation and 
recombination (among others) and the environmental sieving of this variation according to an "evolutionary algorithm" that maximizes fitness. Since genotypic differences among individuals are associated with differences in the propensity for individual survival and reproduction (Mills \& Beatty 1979), an increasing representation of betteradapted individuals in future generations is ensued to the extent that memory, or continuity of information in the form of heritable variation, exists. Most biologists accept the action of this autonomous force (Levin 1998) or «unconscious broker» (Avise \& Ayala 2009) driving adaptive evolution and the emergence of complex structures; NS is the major source of order in the organic world. This classic view of NS is graphically represented in Fig. 1A. Here the environment, or the biotic and abiotic context wherein a population is embedded, is thought to pose «problems» and those individuals best equipped, in terms of possessing heritable «answers» to the posed problems, are endowed with the propensity for better survival and reproduction. This view of evolution by NS, however, captures only part of the processes driving adaptive evolution; as explained below this view should be complemented with sources of order generated within the biological system itself in response to its own structure and dynamics (i.e. selforganization, SO hereafter), which although can be affected by NS, are not necessarily dependent on it for their emergence. The other missing ingredient in the classic Darwinian view of evolution through NS is related to the existence of a fundamental connection between the environment and the organisms within. To put it plainly, these are not independent, the environment is affected by processes carried

(A)

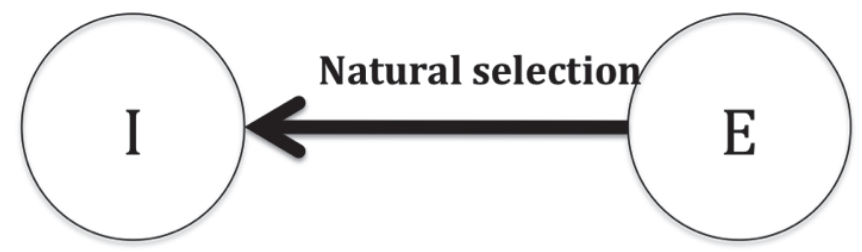

(B)

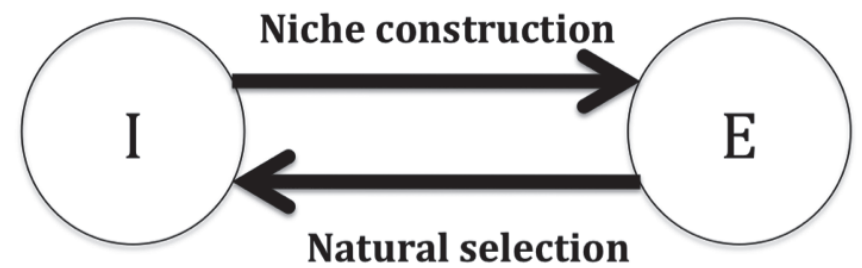

(C)

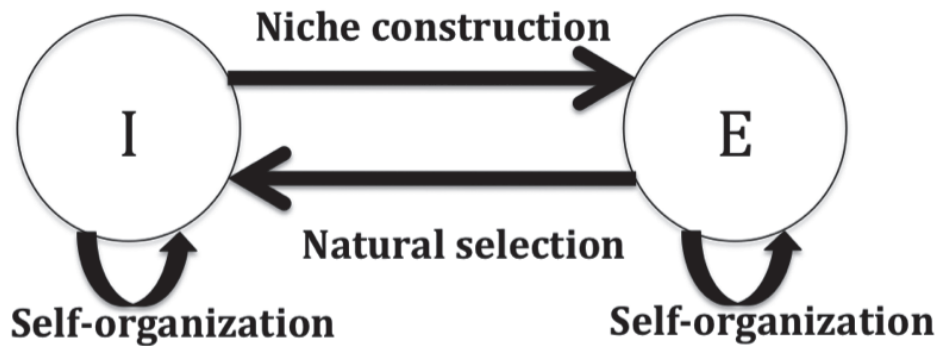

Fig. 1: The progressive and cumulative refinement of the interaction between individual organisms (I) and their environment (E). From Darwin's conceptualization of the environment as a selective filter to population level variation (A) to niche construction (B) to self-organization (C).

El refinamiento progresivo y acumulativo de la interacción entre los individuos (I) y su ambiente (E). Desde la conceptualización de Darwin, donde el ambiente es un filtro a la variación poblacional (A) a la construcción de nicho (B) a la autoorganización. 
out by organisms and similarly, the organism is affected by its environment. Hence, the environment carries the footprint of its past and present inhabitants. This fundamental circularity in the interaction between the organism and its environment, such that the action of the organisms modify their selective environment thereby affecting their own evolution, has been extensively analyzed under the theory of niche construction. In what follows I will briefly discuss these two concepts, which I believe represent major challenges and opportunities for the expansion of evolutionary theory in the Darwinian tradition.

\section{NICHE CONSTRUCTION}

"The aspects of ecology to be considered regard primarily the study of the conditions under which groups of organisms exist. Such groups may be acted upon by their environment, and they may react upon it. If a set of properties in either system changes in such a way that the action of the first system on the second changes, this may cause changes in properties of the second system which alter the mode of action of the second system on the first. Circular causal paths can be established in this manner." (Hutchinson 1948).

“...organisms not only determine what aspects of the outside world are relevant to them by peculiarities of their shape and metabolism but they actively construct, in the literal sense of the word, a world around themselves." (Lewontin 2000).

Organisms are agents of change. Living entities are transient metabolic reactors that produce a transformation in the environment by interacting with energy, matter and information fluxes, with the aim of maintaining their structure and the information needed to recreate it through time. What living entities do to their environment can have important ecological consequences on other organisms in terms of creating habitats or making resources available to them (e.g., through ecological engineering, Jones et al 1994). But more fundamentally, organisms do have an active role in shaping and constructing the environment they inhabit, and in doing so modify the biotic and abiotic sources of natural selection upon them and on other organisms (Fig. 1B). Let us just think on the sharp increase of oxygen concentration in the atmosphere as a consequence of the emergence of photosynthetic metabolism 2.2 Gyr ago. These ideas, which have becoming to be known as "niche construction" re-discover the circular causality that Hutchinson anticipated in his 1948 essay, an excerpt of which is reproduced above, and that Lewontin (1983) and later Odling-Smee et al. (1996, 2003) elaborated in greater detail. To some extent it is puzzling that it took so much time to come to this realization, which albeit its simplicity implies a fundamental shift in the way the environment affects the adaptive evolution of organisms through NS. After niche construction, the environment is no longer an autonomous context independent of the organism, hence adaptation through NS is no longer unidirectional; it becomes a two-way street (Odling-Smee et al. 1996). After all it does take two to tango.

\section{NATURAL SELECTION AND SELF-ORGANIZATION}

The issue brought about by $\mathrm{SO}$ in dynamical systems is that order can emerge for reasons other than adaptive evolution driven by NS solely. In the present context, SO will be defined as the emergence of order and structures in a system as a consequence of its inherent dynamics, that is, internally generated self-perpetuating coherent behavior (Nicolis \& Prigogine 1977) in open non-equilibrium system maintained by fluxes of energy and materials (Fig. 1C). In the last decades the study of these systems have lead to suggest that SO satisfy some thermodynamics principles linked to the dissipation of gradients in free energy, examples of which abound in physical systems. Under this view, SO systems act as a channel through which differences in energy are transformed into structures that help enhance the destruction of gradients (Scheneider \& Kay 1994). It has also been proposed that life (Morowitz \& Smith 2007) as well as planetary weather (e.g. Hoelzer et al. 2006) emerged as a consequence of this process. The issue then is how SO and NS, as sources of order, interact. This question has 
been treated extensively by Stuart Kauffman (e.g. Kauffman 1993) who held the view that NS builds on the order internally provided by SO systems, which in many cases comes into existence despite of NS. A more recent proposal by Hoelzer et al. (2006) points out to a more fundamental interaction between NS and SO, which envisions both $\mathrm{NS}$ and $\mathrm{SO}$ as different realization of the same physical principles. SO systems emerge to dissipate energy flows across gradients, and NS is the way to achieve this and is embedded within the large scale SO biosphere. As suggested by Hoelzer et al. (2006) SO may well provide the right framework to understand the emergence of NS and niche construction may provide the fundamental connection between both.

\section{CONCLUDING REMARKS}

What I have tried to accomplish in this brief essay honoring Darwin's fundamental insight on evolution through natural selection, is to convey a sense of where some of the frontiers facing the study of adaptive evolution lay. This is by no means an exhaustive list, as there are several other exciting ones, such as for example the role of selection in driving the emergence of social complexity in human groups (e.g., Boyd \& Richerson 1985, Bowles 2006) and the role of NS in shaping the architecture of genomes and the process of speciation (Via 2009) to name a few. My personal bias, however, tells me that our views of NS and adaptive evolution can be fundamentally transformed and enriched by articulating the processes of niche construction and selforganization as they capture some fundamental aspects of the world around us; the constructive and transformative role of life and its nonequilibrium, open and self-determined character. The synthesis of these two concepts in the context of adaptive evolution may be feasible and fruitful.

\section{ACKNOWLEDGEMENTS}

I thank FONDAP-FONDECYT 1501-0001, ICM P05-002 and PFB-023 (PAM), the Santa
Fe Institute for its hospitality while writing this essay and Aurora Gaxiola for critically reading it.

\section{LITERATURE CITED}

AVISE JC \& FJ AYALA (eds) (2009) In the light of evolution III: Two centuries of Darwin. National Academy of Sciences, The National Academies Press, Washington D.C. 432 pp.

BOYD R \& PJ RICHERSON (1985) Culture and the evolutionary process. Chicago University Press, Chicago. 340 pp.

BOWLES S (2006) Group competition, reproductive leveling and the evolution of human altruism. Science 314: 1569-1572.

DARWIN C (1859) On the origin of species by means of natural selection or the preservation of favoured races in the struggle for life. John Murray, London. $502 \mathrm{pp}$.

HOELZER GA, E SMITH \& JW PEPPER (2006) On the logical relationship between natural selection and self-organization. Journal of Evolutionary Biology 19: $1785-1794$.

HUTCHINSON GE (1948) Circular causal systems in ecology. Annals of the New York Academy of Sciences 50: 221-246.

JONES CG, JH LAWTON \& M SHACHAK (1994) Organisms as ecosystem engineers. Oikos 69: 373386.

KAUFFMAN SA (1993) The origins of order: Selforganization and selection in evolution. Oxford University Press, New York. 709 pp.

LEVIN SA (1998) Ecosystems and the biosphere as complex adaptive systems. Ecosystems 1: 431-436.

LEWONTIN RC (1983) Gene, organism, and environment. In: Bendall DS (ed) Evolution from molecules to men: 151-172. Cambridge University Press, Cambridge

LEWONTIN RC (2000) The triple helix: Gene, organism, and environment. Harvard University Press, Cambridge. 192 pp.

MILLS SK \& JH BEATTY (1979) The propensity interpretation of fitness. Philosophy of Science 46: 263-286.

MOROWITZ H \& E SMITH (2007) Energy flow and the origin of life. Complexity 13: 51-59.

NICOLIS C \& I PRIGOGINE (1977) Self-organization in nonequilibrium systems: From dissipative structures to order through fluctuations. John Wiley \& Sons, New York. 512 pp

ODLING-SMEE FJ, KN LALAND \& MW FELDMAN (2003) Niche construction. American Naturalist 147: 641-648.

ODLING-SMEE FJ, KN LALAND \& MW FELDMAN (2003) Niche construction: The neglected process in evolution. Monographs in Population Biology 37. Princeton University Press, Princeton, NJ. 472 pp.

SCHNEIDER ED \& JJ KAY (1994) Complexity and thermodynamics. Towards a new ecology. Futures 26: 626-647.

VIA S (2009) Natural selection in action during speciation. In: Avise JC \& FJ Ayala (eds) In the light of evolution III: Two centuries of Darwin: 5-26. National Academy of Sciences, The National Academies Press, Washington D.C. 